\title{
PENGARUH MODEL PEMBELAJARAN KOOPERATIF TIPE INSIDE-OUTSIDE CIRCLE (IOC) TERHADAP HASIL BELAJAR SISWA KELAS X TKJ PADA MATA PELAJARAN SIMULASI DIGITAL DI SMK AL-HIKAM BANGKALAN Nuraniya ${ }^{1}$, Puji Rahayu Ningsih ${ }^{2}$, Muchamad Arif ${ }^{3}$ Universitas Trunojoyo Madura nuraniyahrani@gmail.com
}

\begin{abstract}
Abstrak
Penelitian ini bertujuan untuk mengetahui pengaruh model pembelajaran kooperatif tipe Inside-Outside Circle (IOC) terhadap hasil belajar siswa pada mata pelajaran simulasi digital kelas X TKJ di SMK Al-Hikam Bangkalan yang dilihat dari: 1) Hasil belajar siswa, 2) keterlaksanaan pembelajaran, dan 3) respon siswa terhadap pembelajaran. Penelitian ini merupakan penelitian kuantitatif yang menggunakan Quasi Eksperimental Design dengan desain penelitian Nonequivalent Control Group Design. Sampel yang digunakan adalah sampel jenuh, semua anggota populasi dijadikan sampel yaitu kelas X TKJ di SMK Al-Hikam Bangkalan sebanyak 84 siswa yang terdiri dari 42 siswa kelas eksperimen dan 42 siswa kelas kontrol. Instrumen yang digunakan adalah tes hasil belajar berupa pretest dan posttes, lembar observasi aktivitas guru, lembar observasi aktivitas siswa, dan angket respon siswa. Hasil penelitian diperoleh rata-rata hasil belajar posttest kelas eksperimen sebesar 76,54 dan posttest kelas kontrol sebesar 67,73. Berdasarkan hasil uji statistic diperoleh $t_{\text {hitung }}=4,4565>t_{\text {tabel }} 2,0211$, maka Ho ditolak dan Ha diterima, artinya ada pengaruh yang signifikan pada penggunaan model pembelajaran kooperatif tipe Inside-Outside Circle (IOC) terhadap hasil belajar siswa pada mata pelajaran simulasi digital. Hal ini diperkuat dengan hasil observasi aktivitas guru sebesar 97\% dengan kategori sangat baik dan aktivitas siswa sebesar $84 \%$ dengan kategori baik. Kemudian dari perhitungan angket respon diperoleh hasil $90 \%$ dengan kategori sangat kuat. Kata-kata Kunci: Hasil Belajar, Model Pembelajaran Kooperatif Tipe Inside-Outside Circle (IOC), Simulasi Digital
\end{abstract}

\section{Abstract}

This study aims to determine the effect of cooperative learning model of Inside-Outside Circle (IOC) type on student learning outcomes in the subjects of digital simulation of class X TKJ in SMK Al-Hikam Bangkalan seen from: 1) Student learning outcomes, 2) Implementation of learning, and 3) response students towards learning. This research is a quantitative research using Quasi Experimental Design with Noquivalent Control Group Design research design. The sample used is saturated samples, all members of the population sampled the class X TKJ in SMK Al-Hikam Bangkalan as many as 84 students consisting of 42 students experimental class and 42 students of control class. Instrument used is test result of learning in the form of pretes and posttes, observation sheet of teacher activity, observation sheet of student activity, and student response questionnaire. The result showed that the average of experimental class experimental learning result was 76,54 and posttest of control class was 67,73. Based on the statistical test results obtained $t_{\text {hitung }}=4.4565>t_{\text {table }} 2.0211$, then Ho is rejected and Ha accepted, meaning there is a significant influence on the use of cooperative learning model type Inside-Outside Circle (IOC) on student learning outcomes on the subject of simulation digital. This is reinforced by the results of teacher activity observation of $97 \%$ with very good category and $84 \%$ student activity with very good category. Then from the questionnaire responses obtained $90 \%$ results with very strong category.

Key Words: Learning Outcomes, Cooperative Learning Model Type Inside-Outside Circle (IOC), Simulation Digital. 
Menurut Undang-undang No. 20 Tahun 2003 menyatakan Pendidikan Nasional bertujuan mencerdaskan kehidupan bangsa dan mengembangkan manusia Indonesia seutuhnya yaitu manusia Indonesia yang beriman dan bertakwa kepada Tuhan Yang Maha Esa, berbudi pekerti yang luhur, memiliki pengetahuan, ketrampilan, kesehatan jasmani dan rohani. Kepribadian yang mantap dan mandiri serta rasa tanggung jawab kemasyarakatan dan kebangsaan. Melalui pendidikan nasional diharapkan dapat meningkatkan mutu pendidikan dan martabat manusia yang beriman, dan berpengetahuan, berketrampilan, dan memiliki rasa tanggung jawab.

Menurut Sudjana (dalam Anam, 2015: 1) pendidikan adalah suatu interaksi manusia antara pendidik atau guru dengan anak didik atau siswa yang dapat menunjang pengembangan manusia seutuhnya yang berorientasi pada nilai-nilai dan pelestarian serta pengembangan kebudayaan yang berhubungan dengan usaha-usaha pengembangan manusia tersebut. Pendidikan dipandang sebagai salah satu faktor utama yang menentukan pertumbuhan ekonomi, yaitu melalui peningkatan produktivitas tenaga kerja terdidik, dan juga pendidikan dipandang mempunyai peranan penting dalam menjamin perkembangan dan kelangsungan bangsa. Kualitas pendidikan dapat diketahui dari dua hal, yaitu: kualitas proses dan produk.

Berdasarkan hasil wawancara dengan Bapak Suherman, S. Kom selaku guru mata pelajaran Simulasi Digital di SMK
Al-Hikam Bangkalan pada Tanggal 06 November 2017, Jam 11.30 WIB di sekolah tersebut mengatakan bahwa hasil belajar siswa masih rendah. Hal tersebut dapat dilihat saat pembelajaran berlangsung. Ketika guru bertanya tentang pelajaran yang telah disampaikan hanya beberapa siswa yang menjawab pertanyaan yang diberikan guru. Sehingga muncul tanda tanya apakah siswa mengerti materi yang telah disampaikan atau tidak.

Beliau menyatakan bahwa perbandingan siswa yang memiliki nilai tuntas dan siswa yang memiliki nilai tidak tuntas dalam kelas $\mathrm{X}$ TKJ Al-Hikam Bangkalan adalah $40 \%$ berbanding $60 \%$. Hal tersebut terjadi dikarenakan guru saat pembelajaran hanya menggunakan metode ceramah untuk materi yang berkaitan dengan teori sedangkan materi yang berkaitan dengan praktik guru menggunakan metode demonstrasi. Jika guru menggunakan metode ceramah maka siswa akan merasa bosan, sehingga siswa kurang memperhatikan apa yang disampaikan oleh guru. Beliau juga menyatakan bahwa dalam proses pembelajaran tidak menerapkan model pembelajaran. Seharusnya dalam membuat Rencana Perangkat Pembelajaran (RPP) guru harus menetukan model apa yang digunakan. Hal ini dikarenakan beliau lulusan nonpendidikan. Padahal saat ini sudah banyak model-model pembelajaran terbaru. Oleh karena itu, alternatif yang dapat digunakan untuk permasalahan tersebut yaitu dengan menggunakan model pembelajaran kooperatif.

Berdasarkan identifikasi masalah, maka rumusan masalah penelitian sebagai 
berikut: 1). Bagaimana pengaruh model pembelajaran kooperatif tipe InsideOutside Circle (IOC) terhadap hasil belajar siswa kelas X TKJ pada mata pelajaran simulasi digital di SMK Al-Hikam Bangkalan? 2). Bagaimana keterlaksanaan pembelajaran menggunakan model pembelajaran kooperatif tipe InsideOutside Circle (IOC) terhadap hasil belajar siswa kelas $\mathrm{X}$ TKJ pada mata pelajaran simulasi digital di SMK Al-Hikam Bangkalan? 3). Bagaimana respon siswa menggunakan model pembelajaran kooperatif tipe Inside-Outside Circle (IOC) terhadap hasil belajar siswa kelas $\mathrm{X}$ TKJ pada mata pelajaran simulasi digital di SMK Al-Hikam Bangkalan?

Berdasarkan rumusan masalah tersebut maka tujuan penelitian sebagai berikut: 1). Untuk mengetahui bagaimana pengaruh model pembelajaran kooperatif tipe metode Inside-Outside Circle (IOC) terhadap hasil belajar siswa kelas $\mathrm{X}$ TKJ pada mata pelajaran simulasi digital di SMK AlHikam Bangkalan. 2). Untuk mengetahui bagaimana keterlaksaan pembelajaran menggunakan model pembelajaran kooperatif tipe Inside-Outside Circle (IOC) terhadap hasil belajar siswa kelas X TKJ pada mata pelajaran simulasi digital di SMK Al-Hikam Bangkalan. 3). Untuk mengetahui bagaimana respon siswa menggunakan model pembelajaran kooperatif tipe Inside-Outside Circle (IOC) terhadap hasil belajar siswa kelas X TKJ pada mata pelajaran Simulasi Digital di SMK Al-Hikam Bangkalan.

Menurut Suprijono (dalam Indaryanti, 2016: 4), model pembelajaran kooperatif tipe Inside-Outside Circle (IOC) adalah suatu model pembelajaran kooperatif yang terdiri dari dua kelompok siswa yang berpasangan membentuk lingkaran. Menurut Shoimin (2014, 87-88) model pembelajaran kooperatif tipe InsideOutside Circle (IOC) adalah model pembelajaran dengan sistem lingkaran kecil dan lingkaran besar yang diawali dengan pembentukan kelompok besar dalam kelas yang terdiri dari kelompok lingkaran dalam dan kelompok lingkaran luar. Angoota kelompok lingkaran luar berdiri menghadap ke dalam. Antara anggota lingkaran dalam dan luar saling berpasangan dan berhadaphadapan, di mana siswa saling membagi informasi pada saat bersamaan dengan pasangan yang berbeda dengan singkat dan teratur. Kemudian, siswa berada di lingkaran kecil diam di tempat, sementara siswa yang berada di lingkaran besar bergeser satu atau dua angkah searah jarum jam sehingga masing-masing siswa mendapat pasangan baru.

Adapun informasi yang saling dibagikan merupakan isi materi yang mengarah pada tujuan pembelajaran. Pada saat berbagi informasi, semua siswa akan saling memberi dan menerima informasi pembelajaran. Tujuan pembelajaran ini adalah melatih siswa belajar mandiri dan berbicara menyampaikan informasi kepada orang lain. Selain itu juga melatih kedisiplinan dan ketertiban.

\section{METODE PENELITIAN}

Jenis penelitian yang digunakan adalah penelitian kuantitatif dengan pendekatan eksperimen. Menurut Sugiyono (2012: 109) 
penelitian eksperimen adalah metode penelitian yang digunakan untuk mencari pengaruh perlakuan tertentu terhadap yang lain dalam kondisi yang terkendalikan. Desain penelitian yang digunakan adalah quasi experimental design. Menurut Sugiyono (2014: 77) bentuk desain ini merupakan pengembangan dari true eksperimental design, yang sulit dilaksanakan. Dengan tipe nonequivalent control group design. Populasi dalam penelitian ini adalah seluruh siswa SMK Al-Hikam Bangkalan Kelas X Teknik Komputer dan Jaringan (TKJ). Pada penelitian ini populasi kurang dari 100 yaitu 84 siswa maka semuanya dijadikan sampel. Ketentuan pengambilan sampel dalam penelitian ini adalah 42 siswa kelas X TKJ 1 sebagai kelompok kontrol dan 42 siswa kelas X TKJ 2 sebagai kelas eksperimen.

Teknik pengumpulan data dalam penelitian skripsi ini menggunakan tes, observasi dan angket. Instrumen dalam penelitian ini adalah tes hasil belajar, lembar observasi aktivitas guru, lembar observasi aktivitas siswa dan angket respon siswa. Analisis data yang digunakan yaitu uji validitas, taraf kesukaran soal, dan beberapa uji prasyarat. Uji prasyarat yang digunakan dalam penelitian ini diantaranya: uji normalitas, uji homogenitas, uji linier, uji, regresi linier sederhana, hipotesis (uji t) dan uji gain.

\section{HASIL PENELITIAN DAN PEMBAHASAN}

\section{Hasil data pretest dan posttest}

Soal pretest dibagikan sebelum kegiatan proses pembelajaran berlangsung kepada kelas eksperimen dan kelas kontrol. Sedangkan soal posttest diberikan kepada kelas eksperimen dan kelas kontrol setelah kegiatan proses pembelajaran. Adapun hasil pretest kelas eksperimen dan kelas kontrol.

Tabel 4.1 Nilai Pretest dan Posttest Kelas Eksperimen dan Kelas Kontrol

\begin{tabular}{|l|c|c|}
\hline \multicolumn{1}{|c|}{ Kelas } & $\begin{array}{c}\text { Rata-rata } \\
\text { prestest }\end{array}$ & $\begin{array}{c}\text { Rata-rata } \\
\text { posttest }\end{array}$ \\
\hline Kontrol & 34,88 & 67,73 \\
\hline Eksperimen & 47,73 & 76,54 \\
\hline
\end{tabular}

Berdasarkan tabel 4.1 Rata-rata nilai pretest kelas kontrol yaitu 34,88 dan nilai pretest kelas eksperimen yaitu 47,73. Sedangkan rata-rata nilai posttest kelas kontrol yaitu 67,73 dan nilai pretest kelas eksperimen yaitu 76,54.

\section{Uji Signifikansi Hasil Belajar}

Uji hipotesis dilakukan setelah semua uji prasyarat terpenuhi yaitu diantaranya uji normalitas, uji homogenitas, uji linieritas, dan uji regresi linier sederhana. Uji ini bertujuan untuk membuktikan hipotesis yang menyatakan ada pengaruh signifikan antara variabel $\mathrm{X}$ dan $\mathrm{Y}$, untuk mengetahui apakah Ho ditolak atau diterima dapat dilakukan dengan cara membandingkan antara $t_{\text {tabel }}$ dan $t_{\text {hitung. Adapun hipotesis }}$ pada uji hipotesis adalah sebagai berikut:

$\mathrm{H}_{\mathrm{o}}$ : Tidak terdapat pengaruh model pembelajaran kooperatif tipe InsideOutside Circle (IOC) terhadap hasil belajar siswa kelas $\mathrm{X}$ TKJ pada mata pelajaran simulasi digital di SMK Al-Hikam Bangkalan.

$\mathrm{H}_{\mathrm{a}}$ : Terdapat pengaruh model pembelajaran kooperatif tipe Inside-Outside Circle (IOC) terhadap hasil belajar siswa kelas X TKJ pada mata pelajaran simulasi digital di SMK Al-Hikam Bangkalan.

Dengan kaidah pengujian sebagai berikut: 
Jika, $t_{\text {hitung }}>t_{\text {tabel }}$ tu $t_{\text {hitung }}<$ $-t_{\text {tabel }}$, maka Ho diterima

Jika $t_{\text {hitung }}>t_{\text {tabel }}$, maka Ho ditolak

Hasil perhitungan $t_{\text {hitung }}$ sebesar 4,4565 dan $t_{\text {tabel }}$ sebesar 2,0211, maka Ha diterima, artinya terdapat pengaruh yang signifikan model pembelajaran kooperatif Tipe Inside-Outside Circle (IOC) terhadap hasil belajar siswa kelas X TKJ pada mata pelajaran simulasi digital di SMK AlHikam Bangkalan.

\section{Hasil Observasi Aktivitas Guru}

Lembar observasi aktivitas guru dalam penelitian ini digunakan untuk mengetahui aktivitas guru selama pelajaran berlangsung di dalam kelas dengan menggunakan model pembelajaran kooperatif tipe InsideOutside Circle (IOC) pada materi komunikasi dalam jaringan. Observasi aktivitas guru dalam penelitian ini yaitu kesesuaian pelaksanaan pembelajaran dengan langkah-langkah pembelajaran yang sesuai dengan RPP (Rencana Pelaksanaan Pembelajaran). Cara pengukuran melalui moetode observasi secara penuh dari kegiatan pendahuluan hingga kegiatan penutup.

Tabel 4.2 Hasil Observasi Aktivitas Guru

\begin{tabular}{|c|c|c|c|}
\hline & $\begin{array}{c}\text { Pertemua } \\
\text { n ke 1 }\end{array}$ & $\begin{array}{c}\text { Pertemua } \\
\text { n ke 2 }\end{array}$ & $\begin{array}{c}\text { Rata } \\
\text {-rata }\end{array}$ \\
\hline Skor & 88 & 88 & \multirow{2}{*}{$97 \%$} \\
\hline $\begin{array}{c}\text { Persentas } \\
\text { e }\end{array}$ & $97 \%$ & $97 \%$ & \\
\hline
\end{tabular}

Berdasarkan tabel 4.2 menunjukkan pada pertemuan pertama memperoleh skor 97\% sedangkan pada pertemuan kedua memperoleh skor 97\%. Dan rata-rata persentase keseluruhan pada pertemuan pertama dan pertemuan kedua yaitu $97 \%$. Maka, kemampuan guru mengola pembelajaran menggunakan model pembelajaran kooperatif tipe InsideOutside Circle (IOC) tergolong "sangat baik".

\section{Hasil Observasi Aktivitas Siswa}

Observasi aktivitas siswa bertujuan untuk mengetahui sejauh mana aktivitas siswa selama proses pembelajaran berlangsung dengan menggunakan model pembelajaran kooperatif tipe InsideOutside Circle (IOC).

Tabel 4.3 Hasil Observasi Aktivitas Siswa

\begin{tabular}{|c|c|c|c|c|}
\hline $\begin{array}{c}\text { Pertem } \\
\text { uan }\end{array}$ & $\begin{array}{c}\text { Rata- } \\
\text { rata } \\
\text { Nilai } \\
\text { Aktivi } \\
\text { tas } \\
\text { Siswa }\end{array}$ & $\begin{array}{c}\text { Persent } \\
\text { ase }\end{array}$ & $\begin{array}{c}\text { Rata- } \\
\text { rata } \\
\text { Persent } \\
\text { ase }\end{array}$ & $\begin{array}{c}\text { Krite } \\
\text { ria }\end{array}$ \\
\hline 1 & 983 & $83 \%$ & \multirow{2}{*}{$84 \%$} & Baik \\
\hline 2 & 1002 & $85 \%$ & & \\
\hline
\end{tabular}

Berdasarkan tabel 4.3 hasil obsevasi aktivitas siswa diperoleh skor pada pertemuan pertama sebesar 983 dengan persentase $83 \%$ dan pertemuan kedua diperoleh skor 1002 dengan persentase $85 \%$. Dan rata-rata persentase dari pertemuan 1 dan pertemuan 2 yaitu $84 \%$. Maka, aktivitas siswa dalam pembelajaran menggunakan model pembelajaran kooperatif tipe Inside-Outside Circle (IOC) tergolong "baik".

\section{Hasil Angket Respon Siswa}

Angket respon siswa digunakan untuk mengetahui persentase respon siswa terhadap pembelajaran dengan model pembelajaran kooperatif tipe Inside- 
Outside Circle (IOC). Angket respon siswa dibagikan kepada siswa kelas eksperimen setelah menerima pembelajaran menggunakan model pembelajaran kooperatif tipe Inside-Outside Circle (IOC) setelah pertemuan ke-2.

Tabel 4.4 Hasil Angket Respon

\begin{tabular}{|c|c|c|c|}
\hline $\begin{array}{c}\text { Skor } \\
\text { Total }\end{array}$ & $\begin{array}{c}\text { Rata- } \\
\text { rata }\end{array}$ & Persentase & Kategori \\
\hline 2839 & 67 & $90 \%$ & $\begin{array}{c}\text { Sangat } \\
\text { Kuat }\end{array}$ \\
\hline
\end{tabular}

Berdasarkan tabel 4.5 hasil angket respon siswa diperoleh skor total 2839 dengan rata-rata 67 dan dengan persentase 90\% dan angket respon siswa berkategori "sangat kuat".

\section{PENUTUP}

\section{Simpulan}

Berdasarkan data hasil penelitian dan pembahasan dapat disimpulkan sebagai berikut: 1). Terdapat pengaruh yang signifikan antara model pembelajaran kooperatif tipe Inside-Outside Circle (IOC) terhadap hasil belajar siswa pada mata pelajaran simulasi digital. Hal ini dibuktikan dengan $t_{\text {hitung }} 4,4565$ lebih besar dari tabel 2,0211, maka Ho ditolak dan $\mathrm{Ha}$ diterima, artinya terdapat pengaruh yang signifikan pembelajaran menggunakan model pembelajaran kooperatif tipe InsideOutside Circle (IOC) berpengaruh terhadap hasil belajar siswa kelas X TKJ pada mata pelajaran simulasi digital di SMK AlHikam Bangkalan. Hasil uji gain ternormalisasi pada penelitian ini mendapatkan nilai rata-rata sebesar 0.55 dengan kategori "sedang". Artinya, pembelajaran menggunakan model pembelajaran kooperatif tipe InsideOutside Circle (IOC) berpengaruh terhadap hasil belajar siswa kelas X TKJ pada mata pelajaran simulasi digital di SMK AlHikam Bangkalan. Hal tersebut juga diperkuat dari regresi linier sederhana dengan persamaan $\mathrm{Y}=54,0953+0,4703 . \mathrm{X}$ bahwa arah garis semakin meningkat. 2). Keterlaksanaan pembelajaran yang ditinjau dari observasi aktivitas guru dengan menggunakan model pembelajaran kooperatif tipe Inside-Outside Circle (IOC) observasi aktivitas guru yang telah dilaksanakan pada pertemuan pertama mendapatkan persentase sebesar 97\% termasuk kategori "sangat baik", dan pada pertemuan kedua mendapatkan persentase sebesar 97\% termasuk kategori "sangat baik", sehingga rata-rata dari kedua pertemuan tersebut sebesar $97 \%$ dengan kategori "sangat baik". Artinya kemampuan guru dalam mengola pembelajaran menggunakan model pembelajaran kooperatif tipe Inside-Outside Circle (IOC) tergolong "sangat baik". Dan keterlaksanaan pembelajaran yang ditinjau dari observasi aktivitas siswa dengan menggunakan model pembelajaran kooperatif tipe Inside-Outside Circle (IOC) yang telah dilaksanakan pada pertemuan pertama mendapatkan persentase sebesar $83 \%$ dan pada pertemuan kedua mendapatkan persentase sebesar $85 \%$. Sehingga rata-rata dari kedua pertemuan tersebut sebesar $84 \%$ dengan kategori "baik". Berdasarkan persentase rata-rata observasi aktivitas siswa dalam setiap indikator menunjukkan telah tercapainya kriteria keberhasilan yang ditentukan. 3). Angket respon siswa yang telah dibagikan dan diisi oleh siswa mendapatkan rata-rata 67 dengan persentase sebesar $84 \%$ termasuk kategori "sangat baik" 
Berdasarkan persentase rata-rata angket respon siswa tersebut menunjukkan telah tercapainya kriteria keberhasilan yang ditentukan.

\section{Saran}

Berdasarkan hasil penelitian dan simpulan yang telah dijelaskan, maka peneliti ingin memberikan beberapa saran sebagai masukan dalam meningkatkan kualitas pembelajaran sebagai berikut. 1). Model pembelajaran kooperatif tipe InsideOutside Circle (IOC) dapat digunakan sebagai salah satu alternatif yang dapat digunakan oleh guru dalam meningkatkan hasil belajar siswa. 2). Bagi guru, model pembelajaran kooperatif tipe InsideOutside Circle (IOC) sebaiknya dilakukan secara rutin, karena model pembelajaran ini efisien meningkatkan hasil belajar siswa dalam materi komunikasi dalam jaringan. 3). Model pembelajaran kooperatif tipe Inside-Outside Circle (IOC) dapat dikolaborasikan dengan metode, model, dan pendekatan pembelajaran lainnya. 4). Bagi sekolah, diharapkan memberikan kesempatan guru untuk menyampaikan model pembelajaran aktif yang sesuai dengan karakter materi yang disampaikan.

\section{DAFTAR PUSTAKA}

Akbar, Sa'dun. 2016. Instrumen Perangkat Pembelajaran. Bandung: PT. Remaja Rosdakarya.

Anam, Muchammad Chairil. 2015. Pengaruh Penerapan Model Pembelajaran TSTS (Two Stay Two Stray) Terhadap Hasil Belajar Mata Pelajaran IPS Pada Materi Sejarah
Siswa Kelas X SMK NU 01 Kendal Tahun Ajaran 2014/2015. Semarang: Program Studi Pendidikan Fakultas Ilmu Sosial Universitas Negeri Semarang.

Arifin, Zainal. 2016. Evaluasi Pembelajaran. Bandung: PT. Remaja Rosdakarya

Arikunto, Suharsimi. 2012. Dasar-Dasar Evaluasi Pendidikan Edisi 2. Jakarta: PT. Bumi Aksara.

Fathurrohman, Muhammad. 2015. ModelModel Pembelajaran Inovatif. Jogjakarta: Ar-Ruzz Media.

Gunawan, H. And Darmani, H. 2017. Model dan Strategi Pembelajaran Aktif dan Menyenangkan. Sidoarjo: Nizmia Learning Center.

Hamalik, Oemar. 2016. Proses Belajar Mengajar. Jakarta: PT Bumiaksara.

Hitipeuew, Immanuel. 2009. Belajar dan Pembelajaran. Malang: Fakultas Ilmu Pendidikan Universitas Negeri Malang.

Jihad, Asep dan Abdul Haris. 2012. Evaluasi Pembelajaran. Yogyakarta: Multi Presindo.

Kurniyati, Febti. 2015. Pengaruh Penggunaan Model Pembelajaran Inside-Outside Circle Terhadap Hasil Belajar Siswa Pada Mata Pelajaran Sejarah di Kelas XI IIS 4 SMAN 1 
Boja Kabupaten Kendal Tahun Ajaran 2014/2015. Semarang: Program Studi Sosial Budaya Fakultas Ilmu Sosial Universitas Negeri Semarang.

Megawati, dkk. 2014. Pengaruh Model Pembelajaran Kooperatif Tipe Inside Outside Circle (IOC) Terhadap Hasil Belajar IPA Siswa Kelas V Tahun Pelajaran 2013/2014 di Gugus VII Kecamatan Sawan. E-Journal Mimbar PGSD Universitas Pendidikan Ganesha. Vol: 2. No. 1. Hal 1

Musfiqon. 2012. Panduan Lengkap Metodologi Penelitian Pendidikan. Jakarta: PT. Prestasi pustakarya.

Shoimin, Aris. 2014. 68 Model Pembelajaran Inovatif dalam Kurikulum 2013. Yogyakarta: ArRuzz Media. 
